\title{
Revisiting the Transatlantic Divergence over GM0s: Toward a Cultural-Political Analysis
}

Hannes $R$. Stephan

In the autumn of 2006, the World Trade Organization (WTO) published a longawaited verdict on a divergent regulatory treatment of genetically modified organisms (GMOs) by the United States and the European Union. Adjudicating on the existence of indirect trade barriers, the Dispute Panel found against the Europeans on all major issues. However, with economic power evenly matched and differences deeply rooted, a resolution to the standoff has proved elusive. Many scholars have analyzed the political, economic and legal dynamics of the transatlantic conflict over genetic modification (GM), ${ }^{1}$ but significantly less attention has been devoted to the deeper structural and often cultural reasons behind the underlying divergence. Commentators have mostly drawn on political economy and institutionalism to examine the multiple factors that have generated European and American regulatory frameworks. ${ }^{2}$ Although sociological scholarship has highlighted the ethical, moral, and cultural drivers of public attitudes, ${ }^{3}$ there tends to be only subdued recognition in the literatures on comparative politics and the global governance of agricultural biotechnology (agbiotech) that divergent cultural contexts may constitute an important explanatory element. From a cultural, constructivist perspective, agbiotech has an impact not only on the material practices of agriculture, but it also potentially imperils the cultural meanings attached to food production and consumption. This has been a major, if submerged, motif of European resistance to GMOs.

A cultural-political approach, inspired by interpretive policy analysis, ${ }^{4}$ would highlight the importance of cultural context for political action. It thus provides a complement to agent-centric approaches, illuminates the deeper sources of regulatory trajectories, and may offer clues about the future of regulation in the US and the EU. To ensure the analytical salience of cultural factors,

1. Murphy and Levidow 2006; and Lieberman and Gray 2008.

2. Bernauer 2003; Rosendal 2005; and Levidow and Carr 2009.

3. Wagner et al. 2001; and Schurman and Munro 2009.

4. Yanow 2000. 
this article goes beyond the notion of culture as "webs of significance" 5 and emphasizes widely held moral values and cultural identities.

Before outlining the cultural-political approach, however, the first two sections briefly summarize the transatlantic regulatory divergence over GMOs and review political-economic and institutionalist explanations. The third section inquires into the origins of public attitudes and contends that moral values and cultural identities create the essential, enabling conditions for political mobilization. Fourth, these insights are used to theorize the cultural politics of agbiotech and to show how values and identity-based perceptions shape the opportunity structures for goal-oriented agents. Overall, European cultural contexts structurally enable anti-genetic modification (GM) discourses based on moral claims to flourish, while American anti-GM mobilization has mostly had to rely on less effective utilitarian narratives.

\section{A Brief Overview of Agbiotech Policies}

Although farmers have selected agricultural crops for higher yields or environmental robustness for thousands of years, modern biotechnology clearly represents a step-change. It allows scientists to directly manipulate DNA of individual cells in order to change their genetic make-up and endow plants with desirable traits, such as greater tolerance to particular herbicides or drought conditions. Since the commercialization of GM crops in 1996, global acreage has continuously grown at single or double-digit rates. By the year 2010, it amounted to 148 million hectares in 29 different countries, although the great majority of crops ( 95 percent) were grown in only six countries (USA, Brazil, Argentina, India, Canada, China). ${ }^{6}$ In Europe, GM crops were planted on only 0.119 percent of agricultural land. ${ }^{7}$

The debate over agbiotech has often witnessed contradictory claims about benefits and costs/risks. For example, a beneficial reduction in pesticide use could be negated by target species developing resistance. But such utilitarian rationales have frequently been joined by more specific preoccupations. Although contestation around the world has relied on multiple interests and discourses, anti-GM movements in least developed nations, particularly in Africa, have often expressed their worries about the socio-economic consequences of largescale, "industrial" GM agriculture. Major emerging economies such as China, India, Brazil, South Africa, and Mexico have also recognized the export value of certified non-GM crops. But they have simultaneously developed domestic R\&D capacity and are devoting an increasing acreage to (mainly non-food) GM crops. ${ }^{8}$ American NGOs and consumers have been most interested in the poten-

5. Geertz 1993 [1973], 5.

6. ISAAA 2010.

7. This figure was reported by Howard Davies (Scottish Crop Research Institute) at the AgriGenomics World Congress, London, July 2009.

8. Herring 2008; and Graff et al. 2009. 
tial economic, health and environmental benefits-as well as potential adverse impacts. And European movements have frequently highlighted the ethical and cultural implications of GMOs. ${ }^{9}$

In regulatory terms, there has been remarkable stability in the US since the 1980s and rapid change in the EU between 1997 and 2003, followed by a period of consolidation. In the US, authorizations of agbiotech products are channeled through a long-established regulatory landscape, drawing on the expertise of the US Department for Agriculture (USDA), the Food and Drug Administration (FDA), and the Environmental Protection Agency (EPA). A simple notification procedure is often sufficient and a lengthier authorization process, which includes a full environmental assessment, can be avoided. Once approved, there are no provisions for systematic post-release oversight, as the crops are regarded as "substantially equivalent" to their non-GM relatives.

In contrast, the EU's 1997 Novel Foods Directive, which included relatively moderate provisions on GMOs, quickly became meaningless as a wave of public opposition swept through Europe and led several member state governments to resort to national bans on new GM crops. A raft of new regulations emerged in the early 2000s, containing precautionary clauses on traceability and mandatory labeling, post-release monitoring, and tough thresholds for tolerable "contamination" of non-GM products. A new central scientific body, the European Food Safety Authority (EFSA), was created in 2002 to re-establish scientific credibility and produce authoritative risk assessments of new GM products. ${ }^{10}$ But despite the elaborate regulatory framework, only two GM varieties (MON810 maize and Amflora potatoes) have so far been approved for cultivation, and the Commission's attempts to force countries to repeal their "safeguard" bans have failed.

\section{Principal Explanations of Transatlantic Divergence}

The existing literature on transatlantic regulatory differences has generated important insights. Perspectives drawing on international trade theory and political economy, for instance, sometimes diagnose an instance of European protectionism. ${ }^{11}$ Graff et al. thus argue that rational-and converging-interests of several actor coalitions ultimately explain permissive US regulations and stringent EU laws. European industry could continue to rely on its comparative advantage in chemistry (and conventional pest control products), while farmers would, to some extent, be protected from cheaper imports of GM crops, and ac-

9. Schurman and Munro 2009.

10. Additionally, a recent review by the Directorate-General for Research and Innovation concluded that GMOs "are not per se more risky than e.g. conventional plant breeding technologies" (European Commission 2010).

11. Miller and Conko 2004. 
tivist NGOs could increase their funding base by spearheading the anti-GM movement. ${ }^{12}$

However, while the American regulatory context is dominated by a strong pro-biotech coalition, ${ }^{13}$ there is little evidence that industry and mainstream farming organizations in Europe played a major role in encouraging a stringent regulatory framework. First, large European biotech companies, such as Syngenta or Bayer, compete with American counterparts in international markets and pursue comparable commercial strategies. The interests of European agbiotech companies, irrespective of their size, were not served by the withering of the European market for agbiotech products and the closure or relocation of some of their R\&D facilities. ${ }^{14}$

Second, only a few mainstream farming organizations were originally critical of agbiotech innovations, but emerging consumer hostility turned most farmers away from GMOs. ${ }^{15}$ For example, in the now GM-skeptical France, both government and mainstream farmers initially saw agbiotech as a strategic advantage for economic competitiveness. ${ }^{16}$ The intuition of political-economic analysis remains partially correct, insofar as large biotech companies and the European farming sector did not regard agbiotech innovations as necessary for their economic survival in the short term. The European agricultural system, in particular, has for some time been moving towards less intensive, multifunctional practices which include associated environmental, social, and cultural services. ${ }^{17}$ However, neither the globalized perspective of corporations nor the wider agricultural policy agenda translated into acquiescence or even covert support for stringent regulations.

The most persuasive approaches are concerned with the politicaleconomic mechanisms through which "countervailing forces"18_NGOs and public mobilization-have overcome the influence of agbiotech-friendly actors. Several scholars have demonstrated how public concerns about agbiotech cascaded through economic commodity chains and political systems. ${ }^{19}$ In the EU, concerted NGO campaigns and rising public outrage managed to drive a wedge between the biotech firms, which focus on research and marketing, and the downstream architecture of the chain. Here, a highly concentrated sector of food retailers is vulnerable to concerted consumer boycotts, while a low concentration in European farm, seed, and grain-handling sectors makes it easy to differentiate between GM and non-GM supply chains. ${ }^{20}$ By contrast, in the US,

12. Graff et al. 2009.

13. Toke 2004, 133.

14. Rosendal 2005, 90; and Falkner 2009, 245.

15. Bernauer 2003, 84 .

16. Herring 2008, 461.

17. Morgan et al. 2006, 27.

18. Rosendal 2005.

19. Bernauer 2003; Falkner 2009; and Schurman and Munro 2009.

20. Bernauer 2003, 87f.; and Kurzer and Cooper 2007a. 
downstream actors in the commodity chain are relatively dispersed and not overly vulnerable to competitive pressures from consumers. Most of the major economic players in the US have also steadfastly opposed comprehensive labeling legislation, which may threaten to unravel a largely pro-GM economic architecture. $^{21}$

Another important area of research looks directly at the policy-making process and explores how different institutions and interests groups have influenced political decision-making. The core institutionalist argument is that the combined structural leverage of political systems and regulatory institutions circumscribes the ways in which interest groups and the public can influence political decisions. While US states have little say in the decision-making processes of federal regulatory agencies, EU member states are both the principal agents of enforcement and assume formal political roles in European regulatory committees and, ultimately, the Council of Ministers. A critical mass of skeptical member states was instrumental in supporting a precautionary regulatory attitude. Moreover, European citizens are represented by the European Parliament which treasures its long-standing image of being the advocate of their concerns. ${ }^{22}$

A second strand of institutionalist scholarship analyses the path dependence of regulatory trajectories and argues that "institutional choices taken at critical junctures can persist or become 'locked in', thereby shaping actors strategies later in time." ${ }^{23}$ Some of these historical institutionalists have theorized the ideational components of institutions as regulatory "styles" in order to highlight their built-in biases against socio-economic, cultural or ethical criteria. ${ }^{24}$ Thus, filtered by a strongly science-centric US regulatory framework, these latter concerns have seldom found their way into policy-making debates, except when framed as special interests or personal ethical and religious preferences. In the $\mathrm{EU}$, as I argue below, these other issues have a considerable impact on both public attitudes and policy-making.

While institutionalist approaches add important components to our understanding of the policy-making process, they are less successful in accounting for the relatively swift regulatory changes in Europe witnessed at national and supranational levels. Institutionalists often neglect the fact that the indispensable driver of regulatory reform has been the pressure emanating from public opinion and political mobilization. It was growing public unease that legitimated precautionary leadership by the EU's Environment Directorate-General in the mid-1990s when the advocates of biotechnology were increasingly making the case for laxer regulation.

Political economy perspectives often recognize that it was consumer power which motivated the elimination of GM products from European commodity chains and pushed the European Parliament and some national govern-

21. Smythe 2009.

22. Toke 2004, 180.

23. Pollack and Shaffer 2009, 12.

24. Jasanoff 2005. 
ments to initiate a legislative transformation. In the US, the relative weakness of agbiotech challengers and a lack of sustained public outrage allowed commodity chains and institutional structures to maintain their established routines. In sum, a combination of political economy and institutionalism yields a much richer picture of regulatory dynamics. Yet it may still not inquire into the deeper roots of transatlantic regulatory divergence-that is, the nature of public opinion itself. Such an inquiry, which forms part of a broader cultural-political analysis, indicates that public opinion represents a conduit for deep-seated, historically constituted sentiments that can be linked to moral judgments on agbiotech.

\section{Exploring the Roots of Public Opinion}

Long-term public opinion trends confirm that the scale and intensity of public concerns have broadly corresponded to regulatory change or stability. In the US, public attitudes reached a peak of concern around 2001-2002 when a coalition of NGOs organized a concerted campaign. ${ }^{25}$ Yet, overall public attention proved to be transitory. Over the years, in open questions about food labeling, the issue of unlabelled GM products was a top concern for only 1-2 percent of respondents. ${ }^{26}$ Agbiotech's potential for producing healthier crops or reducing the application of pesticides received the highest support, followed by possible environmental/sustainability advantages. Overall, US public opinion has largely been permissive and informed by utilitarian values.

In the EU, well before the food crises and alleged trigger events of the late 1990s, a groundswell of opposition could be detected, with a sizeable majority of Europeans considering agbiotech applications as harmful and 85 percent of them calling for stricter regulations. ${ }^{27}$ After the peak of public opposition during 1996-2000, attitudes towards agbiotech improved slightly. The Eurobarometer 2005 survey, however, showed that still only 27 percent of respondents regarded GM food positively, and this figure dropped to 23 percent by $2010 .{ }^{28}$ Ultimately, more revealing than numbers as crude indicators are the reasons behind the public's disquiet. These underlying reasons can only be identified by combining survey data with qualitative methods and interpretive approaches. In this vein, several hypotheses have been proposed to explain transatlantic divergence regarding public opinion.

\section{Knowledge and Rational Risk Assessment}

The "deficit model" of the public highlights the lack of scientific knowledge among Europeans. It is used to explain why the conventional diffusion model

25. Reisner 2001; and Schurman and Munro 2009.

26. IFIC 2010.

27. Zechendorf 1994.

28. See Gaskell et al. 2006; and Gaskell et al. 2010. 
of technological progress, which predicts the steady societal uptake of beneficial new technologies, does not always correspond to agbiotech's trajectory. However, survey research has partly falsified this assumption by establishing that - even in the US - textbook knowledge of genetics and GM food only modestly explains more positive opinions. ${ }^{29}$ This strand of explanation is therefore often complemented by conventional risk analysis. Because the media, NGO coalitions and some scientists have emphasized the possibility of (potentially unknown) risks from GMOs to human health and the environment, a rational consumer may conclude that the risks simply outweigh the benefits-in particular because the biotech industry has so far designed its products primarily for its own profit margin and for farmers' yields. ${ }^{30}$

Although conventional risk analysis applies to some extent, it is not clear that risks-even perceived risks-are the principal source of public disquiet in the EU. The term "risk" is missing from many European focus group discussions, while notions of danger figure more often and moral concerns appear to predominate. ${ }^{31}$ Risk has nevertheless become a focal point in the political controversy because regulators are drawn to its technical framing. Moreover, for GM-skeptics the dominance of scientific discourse makes "invoking an uncertain future ... a comfortable way to voice non-specific concerns." 32

\section{Institutional Trust}

A second strand of analysis emphasizes the variable of institutional trust by linking the European public's anxiety about GMOs with a string of food safety and medical scandals in the 1990s. The trustworthiness of government regulators clearly suffered because they failed to predict the dangers posed by the outbreak of mad cow disease (BSE). The event-based argument about trust maintains that these regulatory crises shaped the public's mood, delegitimized official expertise, provided political opportunities for NGOs, and nourished a sensationalist media. ${ }^{33}$ On the other hand, such regulatory crises can equally be understood as non-deterministic through an interpretive lens because Europeans' loss of trust in regulators did not represent a sudden rupture. The sense of a general food and agricultural crisis had pervaded European societies since the 1980 s and the introduction of GMOs was interpreted as a radicalization of this trend. ${ }^{34}$

None of the regulatory failures in the US caused a comparable amount of public disquiet. The 2000 StarLink contamination scandal, in which a GM corn variety solely approved for animal feed was detected in taco shells, opened up a policy window for regulatory reform and started a debate over biosafety, crop

29. Priest 2000 found no significant correlation, but see Ganière et al. 2006.

30. Victor 2001.

31. Bauer et al. 1997, 845 .

32. Wagner et al. 2001, 85 .

33. Ansell and Vogel 2006.

34. Toke 2004, 99. 
segregation and coexistence. ${ }^{35}$ But neither this event nor studies in 1999 and 2001 appearing to show the toxicity of Bt corn (GM) to caterpillars of Monarch butterflies captured the public imagination for long. Americans' confidence in the safety of their food supply and work of regulatory agencies remains at relatively high and stable levels. ${ }^{36}$

From a longer-term perspective, however, once trigger events are reconceptualized as "catalysts," 37 the degree of trust in particular political actors becomes part of the broader cultural context. For instance, Vogel has used polling data to argue that Americans' faith in private corporations rose during the 1980s and 1990s at the expense of public sector institutions and activist NGOs. He claims that, if GMOs had been introduced in the 1970s, the public's reaction would have been less permissive. ${ }^{38}$ This argument implies that there are important contextual factors that are often neglected when focusing on particular events and interest groups.

\section{The Catalytic, Cultural Context}

If, catalysts (rather than triggers) offer a useful description, then the culturalstructural argument should be elaborated. The trust hypothesis highlights that an exact understanding of the mechanics of biotechnology is less important than the perceived legitimacy of the creators and regulators of biotechnological applications. However, as Peters et al. maintain, the more an issue is politicized, the less statistically significant the variable of institutional trust becomes. ${ }^{39}$ Therefore, rather than beginning with a high degree of trust in regulators or corporations and inferring positive public attitudes towards GMOs, it is likely that reverse causality applies and that the affective acceptability of a risk (or technology) shapes the public's trust in the regulator's handling of agbiotech. ${ }^{40}$

Cultural factors are likely to have a significant influence on public opinion because judgments on acceptability are strongly affected by the broader sociocultural context-including dominant worldviews, morality, and cultural identities. ${ }^{41}$ Pardo and Calvo's analysis of the 2002 Eurobarometer survey provides support for this interpretation. The notion of risk did not significantly affect perceptions of usefulness or the moral acceptability of agbiotech, nor did it correlate with the variables emphasized by the deficit model. The authors conclude that the public's judgments were influenced not only by potential practical benefits, but also significantly shaped by worldviews or "orienting dispositions." 42

Some of the public's objections in both the EU and the US were not the

35. Kollman and Prakash 2007, 115.

36. IFIC 2010.

37. Ansell and Vogel 2006, 15.

38. Vogel 2003, 578.

39. Peters et al. 2007, 213.

40. Poortinga and Pidgeon 2005.

41. Earle and Cvetkovich 1995.

42. Pardo and Calvo 2006. 
expression of largely unconscious cultural attitudes, but drew on ethical principles related to the socio-economic impacts of GMOs or to democratic accountability. ${ }^{43}$ At least in Europe, however, positing a sharp demarcation between different groups of opponents would misrepresent the amount of common moral and political ground occupied by the anti-GM movement, especially its critique of narrow conceptions of risk assessment. The success of public mobilization did not principally reflect the convictions of a hard core of activists, but hinged on the cultural values harbored by a majority of European citizens.

In sum, the standard tools of risk analysis offer an incomplete explanation of public outrage which is less based on potential physical risks than on moral vetoes originating in affective dispositions and cultural values.

\section{Towards a Cultural-Political Analysis}

Although some of the above perspectives acknowledge cultural values as one of several important factors ${ }^{44}$, the literature on the transatlantic cultural divide over agbiotech is mainly rooted in socio-legal studies, geography and anthropology. Krenzler and MacGregor, for instance, posit that laws and regulations generally evolve in response to changing conceptions of public policy, which can be traced back to different cultural attitudes. ${ }^{45}$ Echols draws attention to European culinary traditions originating in the Middle Ages and maintains that "[c]ulture and tradition play a silent role in the regulatory process and the resulting rules." 46

What makes these contributions distinctive is their level of societal (or even continental) generalization and their emphasis on two central policy areas-food and agriculture-which are perceived differently on each side of the Atlantic. Admittedly, generalizations on this scale are inherently problematic, particularly in the light of internal American and European differences. But they remain important heuristic tools to identify the potential driving forces, or cultural foundations, of divergent transatlantic patterns. While acknowledging the importance of national subcultures and local specificities, Wagner et al. interpreted conversations from country-level focus groups to signify that "[w]hen it comes to the basic questions pertaining to nature and life, or fear of global technology and economic developments, the European public implicitly demonstrate shared cultural roots [... which] transcend national boundaries, language barriers and north-south contrasts." ${ }^{\prime 7}$ Similarly, although the US contains myriad subcultural formations and regulatory jurisdictions, it is still possible to detect dominant cultural trends and associated processes of attitude formation.

43. Torgersen et al. 2002, 88.

44. Kurzer and Cooper 2007b; and Schurman and Munro 2009.

45. Krenzler and MacGregor 2000.

46. Echols 1998, 543.

47. Wagner et al. 2001, 91. 


\section{Agriculture and Food Cultures}

In European countries, agriculture is generally regarded as an integral part of the environment and the "middle landscape" where human activities and natural processes must coexist. With its associated livelihoods, landscapes, and practices of food production, agriculture is a principal illustration not only of considerable mixture and overlap in land use patterns, ${ }^{48}$ but also of accompanying strong "ideological ... linkages between rural and urban." ${ }^{49}$ The pressures of national and global economic competition have further increased the appeal of traditional agricultural landscapes. Such feelings are most acute in countries where the consequences of agricultural modernization have only grudgingly been tolerated. For instance, for many decades,

in memoirs, films, novels, newspaper articles, academic conferences, and countless town meetings, the French made it clear that they perceived the disappearance of the old rural world not just as an economic or demographic challenge, but as a spiritual loss, a deep wound in the tissue of their civilization. ${ }^{50}$

Because most European societies-geographically and psychologically-continue to emulate the agrarian nations they once embodied, they may be contrasted with a more utilitarian US context.

Thompson thus recounts the story of how the Jeffersonian ideal of the small-holding and fiercely independent yeoman farmer first appeared to flourish with the expanding American frontier and was then smothered by an alliance of industrialist and progressive forces, united in a utilitarian embrace of technology and productivity. ${ }^{51}$ With the exception of certain regions-especially on the East Coast-most American farmland is sharply demarcated from the surrounding industrial estates, suburban housing developments, and spaces of wilderness. Neither regulators nor the public perceive strong positive externalities from agriculture. If a broadly accepted public good is at stake here, it is the production of low-cost food products for the nation. When asked about rural amenities, most US respondents do not reveal a commitment to cultivated, cultural landscapes. And due to a largely productivist farm lobby, outliers with almost "European" preferences-such as the state of Vermont and certain areas of California-generally have little success in obtaining federal subsidies for conservation or alternative farming methods. ${ }^{52}$

A relative transatlantic divergence can also be discerned with regard to food. Historically, the significance of food products and dishes has not only been tied to their life-giving properties, but also corresponds to inherent human practices of "meaning-making." However, the trend towards modernization

48. Peters et al. 2007, 200.

49. Herrick 2005, 291.

50. Bess 2003, 40.

51. Thompson 2001.

52. Baylis et al. 2008. 
through standardization and globalization clashes with the cultural associations of food. By reducing or even eliminating its propensity to carry connotations of social distinction, religious symbolism, cultural belonging and identity, processes of modernization risk triggering a backlash. In many European regions, GM foods are thus often understood as a radicalization of the industrial production process, alluding to efficiency, industrialization, and homogenization. Food cultures frequently represent an essential component of protest against the industrialization of food-and of support for natural products and the return to more traditional culinary roots..$^{53}$

For example, the fusion of food and national identity has attained such a degree in Italy that unwanted innovations (such as GM food) are regarded as alien and "un-Italian." Besides posing a threat to artisanal production methods and the reputation of Italian products, "[o]ne widespread feeling is that Italians do not need to have the genes of the Mediterranean diet mixed in the laboratory with those of arctic fish. ${ }^{\prime 54}$ Even in the strongholds of convenience food, such as Britain,

there is a fast-growing "slow food" movement; after decades of legal adulteration of food, there is now a burgeoning market for natural foods; after decades of enticing consumers to eat world cuisines, there is now a countermove to return to localism, regional foods and real cooking. ${ }^{55}$

The growing interest in the provenance of food and the proliferation of labels and trademarks reflects the rediscovery of "local notions of taste." 56

American food culture shows commonalities with some European countries-especially regarding food safety, nutrition, and price-but its modern evolution distinguishes it from the traditionalist culinary preferences that remain influential in many European societies. ${ }^{57}$ The nationalization of American cuisine during the twentieth century did not raise the standards or glorify authentic ingredients as cultural heritage. Instead, it ushered in the "mass market of industrial cuisine ${ }^{\prime \prime 5}$ whose utilitarian motives are complemented by symbolic associations and images of pleasure. Food advertisement campaigns carry a host of implicit signals about health, vitality and beauty. And these are embedded in a framework of basic American cultural themes: capitalism, industrialism, democracy, pluralism, individualism, leisure, and youthfulness. ${ }^{59}$

However, a burgeoning local food movement is now making inroads into a largely homogenized food system. A coalition of consumer and justiceoriented organizations is attempting to build a broader national consensus around local and regional food systems. It has managed to establish numerous

53. Murdoch and Miele 1999, 466.

54. Sassatelli and Scott 2001, 227.

55. Lang and Heasman 2004, 189.

56. Morgan et al. 2006, 13.

57. Knowlton 2007.

58. Pilcher 2006, 53.

59. Jerome 1977. 
farm-to-school/college programs and helped to double the number of "official" farmers' markets to 7,175 by $2008 .{ }^{60}$ The demonstration of "culinary capital" through detailed knowledge of quality food products and dishes is also becoming increasingly desirable in some sections of society. ${ }^{61}$ Nevertheless, increasing attention to the provenance of food may turn out not to be as intensely associated with images of tradition and/or nature as in Europe. The appeal of local food may sometimes be fruitfully combined with the potential utilitarian benefits of GM crops. ${ }^{62}$

\section{The Cultural Politics of Agbiotech}

Naturally, these cultural contexts do not directly cause specific outcomes, but they are highly influential in shaping the degree of public support for GMOs by offering particular cultural-political opportunities and foreclosing certain alternatives. Thus, by restructuring economic commodity chains, a high level of public outrage in Europe has greatly contributed to the observed regulatory stringency. But how should the overall significance of cultural factors for the politics of agbiotech be assessed?

The answer depends on how culture is conceptualized. Theorists emphasizing the autonomy of political factors or the creative power of discourses hold that public attitudes towards agbiotech are socially constructed, insofar as they correspond to various framings of the issue. Montpetit and Rouillard maintain that "culture should not be reduced to public attitudes measured by opinion surveys or to essential values" because it is "dynamic and always contested." 63 The cultural context might thus be harnessed by what Clapp and Fuchs describe as "discursive power" - the process of "constituting and framing policies, actors, and broader societal norms and ideas" by playing on perceptions of trust and legitimacy. ${ }^{64}$

As the previous section argued, however, agri-food traditions in the US and European countries are not so contradictory to be wholly discursively malleable because they are rooted in historically constituted values and practices. And, in the European case, they are often linked to powerful national and regional identities. A cultural analysis of anti-biotech mobilization goes beyond a discursive approach because it examines the deeper reasons behind the success or failure of particular narratives. Discourses are successful in mobilizing citizens when they resonate with pre-existing cultural values and identities. ${ }^{65}$

The structural, constitutive quality of cultural context means that the ob-

60. Holt-Giménez and Patel 2009, 165ff. For the 2011 figure, see "Farmers Markets and Local Food Marketing," at: http://www.ams.usda.gov/AMSv1.0/FARMERSMARKETS, accessd 30 July 2012.

61. Smith 2009, 273

62. Novotorova and Mazzocco 2008.

63. Montpetit and Rouillard 2008, 927.

64. Clapp and Fuchs 2009, 10f.

65. O'Mahony and Skillington 1999, 112; and Holt-Giménez and Patel 2009, 169. 
jectives of political actors are neither freely conceived nor do they perfectly mirror those of rational agents. Even political elites cannot be regarded as existing entirely apart from their cultural context(s), although, in the longer term, determined actors can help transform this background through reflexive action, thus leading to social learning and solidifying new cultural values that will one day be perceived as constitutive "common sense." Yet, in the short term, a prevailing cultural context is a considerable constraint on goal-oriented political actors.

Many biotechnology companies have been acutely conscious of the different cultural contexts defining their markets. The British company Zeneca Seeds thus carefully selected its first product (American GM tomato puree) in 1996 for entry into the European market, provided clear labeling, and was rewarded with initial success. Shortly afterwards, however, it watched powerlessly when the USbased Monsanto corporation crossed the Atlantic and refused to label its shipments of GM soybeans. Monsanto tried to respond to mounting criticism, but its advertising campaign was badly timed and ill-conceived. The discursive power it intended to project backfired and fuelled the growing public debate.

It is equally important to emphasize that European NGOs have not created the broader societal skepticism towards agbiotech. Instead, they have acted as "opportunistic actors piggy-backing on pre-existing negative public perceptions of agri-biotechnology." ${ }^{66}$ In Europe, numerous social movements and NGO coalitions operate at local, national and supranational levels of policy-making and present a variety of carefully tailored campaign messages. While health and environmental risks are a core staple of the campaign-boosting the movement's scientific and political legitimacy-evocative rhetorical devices have equally flourished, ranging from Britain's Prince Charles' defense of nature as the realm of God to criticism of "aggressive" American capitalism (regarding Monsanto) and savvy combinations of environmental and moral discourse, such as "genetic pollution," "contamination," and "Frankenfoods." 67 These non-utilitarian, often openly moralistic discourses resonated with European publics in a way that cannot be attributed solely to regulatory crises and issues of trust.

The structural role of agricultural traditions and food cultures as symbolic (and material) amplifiers of national cultural identities was a major catalytic influence. For instance, agbiotech's closeness to the practices of industrial agriculture provoked the ire of conservationists in Britain. "This type of genetic modification," English Nature, a major UK government agency, wrote in 1999, "will make farming even more intensive and is undesirable in the British countryside where farming and wildlife must co-exist." 68 Agbiotech was also depicted as a threat to artisanal farmers whose plight had long preoccupied the public's consciousness. Agricultural and food traditions are inextricably connected in some European regions, making it relatively easy for small farm-

66. Bernauer 2003, 69.

67. Schurman and Munro 2009.

68. Lang and Heasman 2004, 181. 
ers' organizations-such as Confédération Paysanne in France or Coldiretti in Italy-to build alliances with consumer and environmental groups. Evoking the agro-food "patrimony" of their nations, activists rhetorically linked GM foods and crops to the decline of family farms and the spread of low-quality "fast" food. ${ }^{69}$

Of course, these cultural dynamics do not apply to all European societies to the same degree. While similar themes and campaigning coalitions emerged in many countries (such as Greece, Cyprus, Malta, Austria, Germany, Luxemburg, Ireland, Slovenia, Poland, the Baltic states, Hungary, Bulgaria), there is no convincing explanatory framework to account for subdued public awareness and debate in a number of countries with strong traditional food cultures (e.g., Portugal, Spain) or burgeoning organic agricultural sectors (e.g., Sweden, Denmark, Finland). Moreover, public opinion trends do not always correlate with the voting patterns of national governments at the European level, ${ }^{70}$ indicating a degree of political autonomy-at least from latent public opposition.

The available literature indicates that agbiotech has not yet been politicized in countries like Portugal and Spain, but surveys also show that public support has gradually diminished. Public debate has equally begun to intensify in the Nordic countries where, until relatively recently, GM crops had virtually been absent from the marketplace. Finally, perhaps the clearest outlier among European countries is the Netherlands where, although public support remains modest, the socio-economic imprint of a strong biotech sector and exportoriented agribusiness is not counterbalanced by a traditionalist food culture. Here, as well as in hitherto GM-skeptical Britain, claims about economic competitiveness and environmental sustainability, as well as ethical arguments about global food supplies, are increasingly influential. ${ }^{71}$

In the US, spearheaded by a broad coalition of NGOs, the anti-GM movement emphasized socio-economic arguments about the corporate take-over of the food chain and the risks posed to small and organic farmers. But the central message aimed at fomenting a consumer revolt and concentrated on the potential utilitarian risks for human health and the environment. ${ }^{72}$ The coalition's demands included more stringent evaluations of potential adverse impacts and the mandatory labeling of GMOs. These demands seem decidedly modest, but one should not underestimate the structural significance of a comprehensive labeling system (or even voluntary non-GM labels) in unleashing "consumer sovereignty" and potentially forcing segregated supply chains for GM and non-GM crops. ${ }^{73}$ Here, both material forms of pro-GM power and discursive strategies "normalizing" agbiotech products have been important.

Despite failing to fundamentally reform the US regulatory framework,

69. Kurzer and Cooper 2007a.

70. Kurzer and Cooper 2007b.

71. Kurzer and Cooper 2007b; Consumerchoice 2008; and Gaskell et al. 2010, 40.

72. Reisner 2001.

73. Smythe 2009 . 
campaigners did score some limited victories. The new organic food labels established in 2002 allowed for an implicit certification of GM-free food, and the FDA issued more stringent guidance on pre-market food safety evaluations in 2004. A flurry of court cases and bills in state legislatures yielded a patchwork of rudimentary segregation and labeling laws. ${ }^{74} \mathrm{~A}$ small number of states from New England have acted as frontrunners, with Maine allowing voluntary labeling of GM-free products and Vermont passing legislation on mandatory GM seed labels. But Vermont's governor vetoed a strict liability law that could have made coexistence of non-GM and GM crops impractical. Besides the strong position of organic farming in New England, "European-style" landscapes and farming systems have clearly fostered an unusually strong "cultural identification" with food and agriculture. ${ }^{75}$ Elsewhere-for instance in California, Arkansas, and Missouri-economic motives have taken center stage, inducing state legislators to preempt the cultivation of GM rice in order to reassure valuable exports markets in Asia.

These developments notwithstanding, a turning point has not been reached in the US. Efforts are continuing, but the generally tenuous connections between food and agriculture, on the one hand, and national or regional identities on the other, constitute an important element of an overall explanation. Moreover, cautious support for GM technology has a long history in the US environmental movement. ${ }^{76}$ Together with well-established mainstream NGOs focusing on the protection of wilderness, the great majority of Americans do not venerate agricultural landscapes, but national parks which represent "a powerful cultural statement fusing notions of nature and nation." 77 Regarding American food culture, even critiques do not refer to convenience food as being in some way "un-American."

In sum, cultural-political dynamics will continue to shape American and European agbiotech regulations. Although both pragmatic regulatory change and a longer-term cultural evolution cannot be ruled out, the cultural factors reviewed here will likely remain essential for understanding regulatory stability and transformation.

\section{Conclusion}

This article has made the case for embedding existing perspectives on the evolution of US and European agbiotech regulation in a broader cultural-political account which privileges contextual over agent-centric analysis. By pursuing a constructivist perspective and by highlighting the catalytic potential of culturalpolitical opportunities, the article aims to shed light on the deeper sources of

74. Kollman and Prakash 2007, 109ff.

75. Tokar 2009.

76. Toke 2004, 16.

77. Beinart and Coates 1995, 90. 
regulatory systems and, by extension, on the persistence of the transatlantic divide. Nonetheless, existing perspectives on regulatory politics constitute an essential element of an overall explanation. Political economy approaches identify public opinion, political mobilization, short-term interests, and the structure of commodity chains as critical elements, but they tend to rely on rational choice and conventional risk analysis to explain the nature of political opposition. Institutionalists draw attention to the entrenchment of organizing principles or regulatory traditions and focus on policy windows and related opportunities.

However, neither approach adequately explains why Europeans' concerns about agbiotech were tangible well before the years of controversy and have not significantly abated since then-or why GM foods and crops have become a "sounding board"78 for a host of issues ranging from the fear of globalization and dilution of national identities to the defense of integrated "agri-cultural" landscapes and food cultures. This broader cultural context-often neglected because it cannot be easily defined or measured-must be considered because the public often relies upon pre-existing moral values and cultural identities to make sense of GM technology. ${ }^{79}$

Nor is there strong evidence that Europeans' perceptions were successfully fashioned or imposed by political elites or corporate actors. Certainly, cultural values and national identities are constantly being reproduced through state institutions and the media. Most of these efforts, such as Italy's state-sponsored food education program-entitled "Culture that Feeds" 80 - have traditionalist objectives that aim to preserve particular societal perceptions of food and agriculture. In most European societies, rather than undergoing radical discursive change, it appears as if traditional conceptions of cultural identity, "naturalness," and moral worldviews have largely endured. In the language of constructivism, as $\mathrm{O}^{\prime}$ Mahony and Skillington have phrased it, "innovations in the social construction of reality are never so transformative as to be culturally unrecognisable ... discourse formations do not so much complement wider systems of cultural or political belief as respond to them in a creative manner." 81

An exploration of cultural contexts also helps to illuminate why in the US, despite some potential regulatory crises, the tailored message of environmental and health risks was insufficient to create widespread public outrage, except for a small number of states and regions. Most Americans privilege low price and convenience over paying heed to potential, albeit fundamentally uncertain, risks. US regulators, backed by influential corporate actors from the Food Chain Network, will arguably continue on the path of technological innovation unless substantial, new risks are uncovered.

78. Torgersen et al. 2002, 23.

79. See Schurman and Munro (2009) for an example of a growing literature on "cultural political economy."

80. Morgan et al. 2006, 197.

81. O'Mahony and Skillington 1999, 101. 
European NGOs, by contrast, were capable of mobilizing large sections of European societies by adding moral discourses to the customary stock of (utilitarian) risk-based arguments. Evidently, these campaigns played out differently in each country. Further research on intra-European differences would have to examine both national cultural contexts and pluralist interest politics to construct a more fine-grained framework for understanding public perceptions of and governments' positions on agbiotech. Such insights would be especially important at a time when the EU's carefully designed supranational system of scientific advice and political regulation may be entering another reformist phase. In the summer of 2009, a group of eleven member states proposed the partial renationalization of agbiotech policy-making in order to enable individual countries to legally uphold national bans, even if based on ethical or cultural grounds. ${ }^{82}$ By July 2011, the European Parliament had produced a list of environmental and socio-economic criteria to ensure a firmer legal footing for national bans. Several member states-such as France, Germany, Britain, Belgium, and Spain-have so far rejected the entire regulatory enterprise. But if this initiative were to succeed, civil society mobilization and the proliferation of GM-free regions may induce some countries to either institute explicit bans on GM varieties or further strengthen their national coexistence regulations to discourage the planting of GM crops, for instance by imposing stiff penalties for even inadvertent contamination of non-GM fields. A small number of pro-GM governments might, in turn, hope to desensitize consumers by allowing the cultivation of GM varieties under lax coexistence legislation, thus undercutting the very notion of non-GM crops and products. However, it remains uncertain whether these countervailing trends would enable GM crops to be planted more widely and GM foods to be stocked by supermarkets alongside non-GM alternatives.

While European consumers may also be susceptible to a logic of utilitarian benefits ${ }^{83}$ - such as lower prices, environmental or health advantages-the cultural values and identities associated with food and agriculture mean that Europeans' cognitive threshold is higher than that of US consumers. As agbiotech supporters have begun to frame their innovations in ethical termsfor instance in relation to alleviating world hunger or resilience to climate change-they may succeed in engaging European societies more positively. This adapted message will not resonate at the same deep level of cultural identity, but it may re-brand agbiotech as an essential element of humanistic "progress." Without a strong (ethical or utilitarian) rationale for agbiotech products, the culturally motivated veto of many European citizens is unlikely to weaken substantially.

82. This group included ten GM-skeptical nations (Austria, Bulgaria, Cyprus, Greece, Hungary, Ireland, Latvia, Lithuania, Malta, Slovenia) and the pro-GM Netherlands.

83. Gaskell et al. 2004. 


\section{References}

Ansell, Christopher and David Vogel. 2006. The Contested Governance of European Food Safety Regulation. In What's the Beef? The Contested Governance of European Food Safety, edited by Christopher Ansell and David Vogel, 3-32. Cambridge, MA: MIT Press.

Bauer, Martin W., John Durant and George Gaskell. 1997. Europe Ambivalent on Biotechnology. Nature 387 (6636): 845-847.

Baylis, Kathy, Stephen Peplow, Gordon Rausser, et al. 2008. Agri-environmental Policies in the EU and United States: A Comparison. Ecological Economics 65 (4): 753-764.

Beinart, William and Peter Coates. 1995. Environment and History: The Taming of Nature in the USA and South Africa. London: Routledge.

Bernauer, Thomas. 2003. Genes, Trade, and Regulation: The Seeds of Conflict in Food Biotechnology. Princeton: Princeton University Press.

Bess, Michael. 2003. The Light-Green Society: Ecology and Technological Modernity in France, 1960-2000. Chicago: University of Chicago Press.

Clapp, Jennifer and Doris Fuchs. 2009. Agrifood Corporations, Global Governance, and Sustainability: A Framework for Analysis. In Corporate Power in Global Agrifood Governance, edited by Jennifer Clapp and Doris Fuchs, 1-25. Cambridge, MA: MIT Press.

Consumerchoice. 2008. Do European Consumers Buy GM Foods? European Commission: Framework 6. Available at http://www.kcl.ac.uk/consumerchoice, accessed 28 June, 2011.

Earle, Timothy C. and George T. Cvetkovich. 1995. Social Trust: Toward a Cosmopolitan Society. Westport: Praeger.

Echols, Marsha A. 1998. Food Safety Regulation in the European Union and the United States: Different Cultures, Different Laws. Columbia Journal of European Law 4 (3): 525-543.

European Commission. 2010. A Decade of EU-funded GMO Research (2001-2010). Brussels: Directorate-General for Research and Innovation.

Falkner, Robert. 2009. The Troubled Birth of the 'Biotech Century': Global Corporate Power and Its Limits. In Corporate Power in Global Agrifood Governance, edited by Jennifer Clapp and Doris Fuchs, 225-251. Cambridge, MA: MIT Press.

Ganière, Pierre, Wen S. Chern and David Hahn. 2006. A Continuum of Consumer Attitudes Toward Genetically Modified Foods in the United States. Journal of Agricultural Resource Economics 31 (1): 129-149.

Gaskell, George, Agnes Allansdottir, Nick Allum, et al. 2006. Europeans and Biotechnology in 2005: Patterns and Trends. Report to the European Commission's DirectorateGeneral for Research.

Gaskell, George, Nick Allum, Wolfgang Wagner, et al. 2004. GM Foods and the Misperception of Risk Perception. Risk Analysis 24 (1): 185-194.

Gaskell, George, Sally Stares, Agnes Allansdottir, et al. 2010. Europeans and Biotechnology in 2010: Winds of Change. Report to the European Commission's DirectorateGeneral for Research.

Geertz, Clifford. 1993 [1973]. The Interpretation of Cultures: Selected Essays. New York: Basic Books.

Graff, Gregory D., Gal Hochman and David Zilberman. 2009. The Political Economy of Agricultural Biotechnology Policies. AgBioForum 12 (1): 34-46. 
Herrick, Clare B. 2005. 'Cultures of GM': Discourses of Risk and Labelling of GMOs in the UK and the EU. Area 37 (3): 286-294.

Herring, Ronald J. 2008. Opposition to Transgenic Technologies: Ideology, Interests and Collective Action Frames. Nature Reviews Genetics 9 (6): 458-463.

Holt-Giménez, Eric and Raj Patel. 2009. Food Rebellions! Crisis and the Hunger for Justice. Cape Town: Pambazuka Press.

International Food Information Council (IFIC). 2010. 2010 'Consumer Perceptions of Food Biotechnology' Survey. Available at http://www.foodinsight.org/Content/3843/Final _Executive\%20Summary\%20Food\%20Tech\%20Report_Website\%20version_77-10.pdf, accessed 28 June 2011.

International Service for the Acquisition of Agri-Biotech Applications (ISAAA). 2010. Global Status of Commercialized Biotech/GM Crops: 2010. ISAAA Brief 42-2010.

Jasanoff, Sheila. 2005. Designs on Nature: Science and Democracy in Europe and the United States. Princeton: Princeton University Press.

Jerome, N. W. 1977. Taste Experience and the Development of a Dietary Preference for Sweet in Humans: Ethnic and Cultural Variations in Early Taste Experience. In Taste and Development, edited by J. M. Weiffenbach, 235-248. Washington, DC: U.S. Government.

Knowlton, Laura. 2007. Reading American Fat in France: Obesity and Food Culture. European Journal of American Studies [Online] (2). Available at http://ejas.revues.org/ document1363.html, accessed 28 June 2011.

Kollman, Kelly L. and Aseem Prakash. 2007. Biopolitics in the US: An Assessment. In The International Politics of Genetically Modified Food: Diplomacy, Trade and Law, edited by Robert Falkner, 103-117. Houndmills: Palgrave.

Krenzler, Horst G. and Anne MacGregor. 2000. GM Food: The Next Major Transatlantic Trade War? European Foreign Affairs Review 5: 287-316.

Kurzer, Paulette and Alice Cooper. 2007a. Consumer Activism, EU Institutions and Global Markets: The Struggle over Biotech Foods. Journal of Public Policy 27 (2): 103-128.

Kurzer, Paulette and Alice Cooper. 2007b. What's for Dinner? European Farming and Food Traditions Confront American Biotechnology. Comparative Political Studies 40 (9): 1035-1058.

Lang, Tim and Michael Heasman. 2004. Food Wars: The Global Battle for Mouths, Minds and Markets. London: Earthscan.

Levidow, Les and Susan Carr. 2009. GM Food on Trial: Testing European Democracy. London: Routledge.

Lieberman, Sarah and Tim Gray. 2008. The World Trade Organization's Report on the EU's Moratorium on Biotech Products: The Wisdom of the US Challenge to the EU in the WTO. Global Environmental Politics 8 (1): 33-52.

Miller, Henry I. and Gregory Conko. 2004. The Frankenfood Myth: How Protest and Politics Threaten the Biotech Revolution. Westport: Praeger.

Montpetit, Eric and Christian Rouillard. 2008. Culture and the Democratization of Risk Management: The Widening Biotechnology Gap Between France and Canada. Administration \& Society 39 (8): 907-930.

Morgan, Kevin, Terry Marsden and Jonathan Murdoch. 2006. Worlds of Food: Place, Power and Provenance in the Food Chain. Oxford: Oxford University Press.

Murdoch, Jonathan and Mara Miele. 1999. 'Back to Nature': Changing 'Worlds of Production' in the Food Sector. Sociologica Ruralis 39 (4): 465-483. 
Murphy, Joseph and Les Levidow. 2006. Governing the Transatlantic Conflict Over Agricultural Biotechnology. London: Routledge.

Novotorova, Nadezhda K. and Michael A. Mazzocco. 2008. Consumer Preferences and Trade-Offs for Locally Grown and Genetically Modified Apples: A Conjoint Analysis Approach. International Food and Agribusiness Management Review 11 (4): 31-53.

O'Mahony, Patrick and Tracey Skillington. 1999. Constructing Difference: Discourse Coalitions on Biotechnology in the Press. In Nature, Risk and Responsibility: Discourses of Biotechnology, edited by Patrick O'Mahony, 100-113. Houndmills: Macmillan.

Pardo, Rafael and Felix Calvo. 2006. Are Europeans Really Antagonistic to Biotech? Nature Biotechnology 24 (4): 393-395.

Peters, Hans P., John T. Lang, Magdalena Sawicka, et al. 2007. Culture and Technological Innovation: Impact of Institutional Trust and Appreciation of Nature on Attitudes Towards Food Biotechnology in the USA and Germany. International Journal of Public Opinion Research 19 (2): 191-220.

Pilcher, Jeffrey. 2006. Food in World History. New York: Routledge.

Pollack, Mark A. and Gregory C. Shaffer. 2009. When Cooperation Fails: The International Law and Politics of Genetically Modified Foods. Oxford: Oxford University Press.

Poortinga, Wouter and Nick F. Pidgeon. 2005. Trust in Risk Regulation: Cause or Consequence of the Acceptability of GM Food. Risk Analysis 25 (1): 199-209.

Priest, Susanna H. 2000. US Public Opinion Divided Over Biotechnology? Nature Biotechnology 18 (9): 939-942.

Reisner, Ann E. 2001. Social Movement Organizations' Reactions to Genetic Engineering in Agriculture. American Behavioral Scientist 44 (8): 1389-1404.

Rosendal, G. Kristin. 2005. Governing GMOs in the EU: A Deviant Case of Environmental Policy-making? Global Environmental Politics 5 (1): 82-104.

Sassatelli, Roberta and Alan Scott. 2001. Novel Food, New Markets and Trust Regimes: Responses to the erosion of consumers' confidence in Austria, Italy and the UK. European Societies 3 (2): 213-244.

Schurman, Rachel and William Munro. 2009. Targeting Capital: A Cultural Economy Approach to Understanding the Efficacy of Two Anti-Genetic Engineering Movements. American Journal of Sociology 115 (1): 155-202.

Smith, Andrew F. 2009. Eating History: 30 Turning Points in the Making of American Cuisine. New York: Columbia University Press.

Smythe, Elizabeth. 2009. In Whose Interests? Transparency and Accountability in the Global Governance of Food: Agribusiness, the Codex Alimentarius, and the World Trade Organization. In Corporate Power in Global Agrifood Governance, edited by Jennifer Clapp and Doris Fuchs, 93-123. Cambridge, MA: MIT Press.

Thompson, Paul B. 2001. The Reshaping of Conventional Farming: A North American Perspective. Journal of Agricultural and Environmental Ethics 14 (2): 217-229.

Tokar, Brian. 2009. Toward Food Sovereignty in Vermont and Northern New England. 19 May. Available at http://www.social-ecology.org/2009/05/toward-foodsovereignty-in-vermont-and-northern-new-england/, accessed 29 June 2011.

Toke, Dave. 2004. The Politics of GM Food: A Comparative Study of the UK, USA, and EU. New York: Routledge.

Torgersen, Helge, Jürgen Hampel and Marie-Louise von Bergmann-Winberg et al. 2002. Promise, Problems and Proxies: Twenty-Five Years of Debate and Regulation in Europe. In Biotechnology: The Making of a Global Controversy, edited by Martin W. Bauer and George Gaskell, 21-94. Cambridge: Cambridge University Press. 
Victor, David G. 2001. Trade, Science, and Genetically Modified Foods. Council on Foreign Relations. Available at http://www.cfr.org/publication/8689/trade_science_ and_genetically_modified_foods.html?excerpt=1, accessed 28 June 2011 .

Vogel, David. 2003. The Hare and the Tortoise Revisited: The New Politics of Consumer and Environmental Regulation in Europe. British Journal of Political Science 33 (4): $557-580$.

Wagner, Wolfgang, Nicole Kronberger and George Gaskell et al. 2001. Nature in Disorder: The Troubled Public of Biotechnology. In Biotechnology 1996-2000: the years of controversy, edited by George Gaskell and Martin W. Bauer, 80-95. London: Science Museum.

Yanow, Dvora. 2000. Conducting Interpretive Policy Analysis. Thousand Oaks, CA: Sage.

Zechendorf, Bernhard. 1994. What the Public Thinks About Biotechnology. Bio/ Technology 12: 870-875. 